\title{
ЦИТ: иа217-052
}

DOI: 10.21893/2415-7538.2017-06-1-052

УДК 004.378

\section{Дудченко О.М., Федіна I.В., Носова Г.В., Новиков В.I. ФОРМАЛЬНА МОДЕЛЬ РИЗИКІВ НАВЧАЛЬНО- ВИРОБНИЧОЇ СИСТЕМИ \\ Наџіональний університет кораблебудування ім. Адмірала Макарова, Миколаїв, проспект Героїв Сталінграда, 9, 54025}

Dudchenko O.M., Fedina I.V., Nosova G.V., Novikov V.I. FORMAL RISK MODELS EDUCATION AND PRODUCTION SYSTEMS

National University of Shipbuilding. Admiral Makarov, Nikolaev, Prospect Heroes of Stalingrad, 9, 54025

Анотачія. Розглядається підхід побудови математичної моделі складноі системи з метою врахування численних навчально-виробничих факторів. Для формалізаиії було використано структури у вигляді орієнтованого графа $i$ зовнішнього негативного впливу на систему у вигляді імпульсного впливу. Відповідно до иього, автономний імпульсний вплив в парі з вектором початкових значень описує стан системи в початковий момент часу, коли під вплив зовнішніх вражаючих впливів потрапляють всі елементи системи. Таким чином на орграфі можна ввести різні критерії досягнення системою граничного стану, що передбачить негативні наслідки у системі.

Ключеві слова: моделювання складних систем, безпека, зовнішній вплив

Abstract. The approach of mathematical modelling complex systems to take account of the many training and production factor. To formalize the structure was used as a directed graph and external negative impact on the system as a pulsed exposure. Accordingly, the standalone pulse effect in tandem with the vector of initial values describing the state of the system at the initial time when the influence of external impacts damaging contains all elements of the system. Thus the directed graph can enter different criteria for achieving the ultimate state system that can predict the negative effects on the system.

Key words: modelling of complex systems, security, external influence

Вступ. Одним зі складних багатофакторних процесів $\epsilon$ комбінований навчальний процес, що включає теоретичні та практичні заняття. На старших курсах технічних спеціальностей частина практичних і лабораторних занять, навчальних i спеціальних практик значно зростає. У зв'язку 3 такою особливістю організації навчального процесу виникає ряд ризиків пов'язаних 3 безпекою на робочому місці і охороною праці при проведенні практичних занять серед студентів що не мають досвіду практичної роботи.

В даному аспекті слід розглядати такий комбінаційний навчальний процес, як складну багатофакторну систему.

Моделювання складних систем дозволяє досліджувати особливості їх функціонування в різних умовах, наділяти їх необхідними характеристиками $\mathrm{i}$ знижувати ризик виникнення надзвичайних ситуацій у навчанні. У зв'язку з цим $\epsilon$ підстави припустити, що побудова математичної моделі складної системи 3 
метою врахування численних навчально-виробничих факторів $\epsilon$ актуальним завданням.

У математичної моделі досліджуваної системи організації навчального процесу повинні бути представлені основні елементи, моделі поведінки студентів, складність обладнання та ін.. завдяки чому можна достовірно судити про систему загалом [1-3]. Для формалізації доцільно використовувати структури у вигляді орієнтованого графа і зовнішнього негативного впливу на систему у вигляді імпульсного впливу.

3 точки зору концепції безпеки [4], Яку складну систему слід вивчати 3 трьох основних позицій: надійності системи, живучості системи і їі безпеки.

Існують різні види зовнішніх впливів, що впливають на систему. Вплив може бути - емоційний, механічний, термічний, електромагнітний, біохімічний, радіаційний, гідродинамічний та ін. Будь-який вплив викликає підвищення навантаження на ті чи інші елементи системи. Підвищення навантаження на окремо взятий елемент системи впливає на можливості цього елемента виконувати свої функції.

Встановлення зв'язку між навантаженнями, викликаними діями різного роду, як уже зазначалося, є однією з важливих задач механіки катастроф в умовах негативного прояву людського фактору. Встановлення такого зв'язку дозволяє ввести функціонал

$$
\zeta=\Phi\left(\sigma_{i 1}(t), \sigma_{i 2}(t), \ldots, \sigma_{i n}(t)\right)
$$

задає залежність показника якісного стану деякого елемента системи від навантажень $\sigma_{i 1}, \sigma_{i 2}, \ldots, \sigma_{i n}$, викликаних зовнішніми впливами в момент часу $t$. Для систем, всі елементи яких є однорідними, функціонал (1) має вигляд:

$$
\zeta_{M}=\Phi\left(\sigma_{D}(t), \sigma_{N}(t)\right)
$$

де як показник якісного стану $\zeta_{M}$ елементів системи виступає пошкодження, накопичені елементом до моменту часу $t$. Деформація $\sigma_{D} \mathrm{i}$ напруга $\sigma_{N}$, що виникають у елемента системи, служать кількісними уявленнями отриманих при зовнішніх впливах навантажень і поразок.

Як показує практика, складні системи складаються 3 взаємодіючих елементів різної природи (людського фактору, механічної, радіоелектронної та ін..). Тому не для всіх складних систем вдається точно відтворити функціонал (1), в лівій частині якого як показник якісного стану елемента системи виступають накопичені за час зовнішнього вражаючого впливу пошкодження. У такій ситуації показником якісного стану елемента розумно використовувати його надійність. Надійність елемента зменшується при отриманні ним пошкоджень, викликаних зовнішніми впливами.

Функціонування системи передбачає постійну взаємодію утворюючих його елементів. Тому зовнішні впливи, заподіявши пошкодження одним елементам системи, вплинуть на показники якісного стану (надійності) і тих елементів, які не піддалися впливу безпосередньо. Тобто підвищення навантаження буде спостерігатися не тільки у тих елементів системи, які опинилися під впливом зовнішніх факторів, але і у елементів, що взаємодіють з ними. Це призведе до 
зниження надійності у останніх.

Слідуючи відомим підходам щодо підвищення надійності систем i ïx елементів, не представляється можливим продублювати всі елементи системи, яка передбачає потрапляння під зовнішній вплив. Тому потрібно вивчити реакцію системи на "сторонній" вплив, знайти найбільш вразливі "місця" системи і рекомендувати їх до резервування.
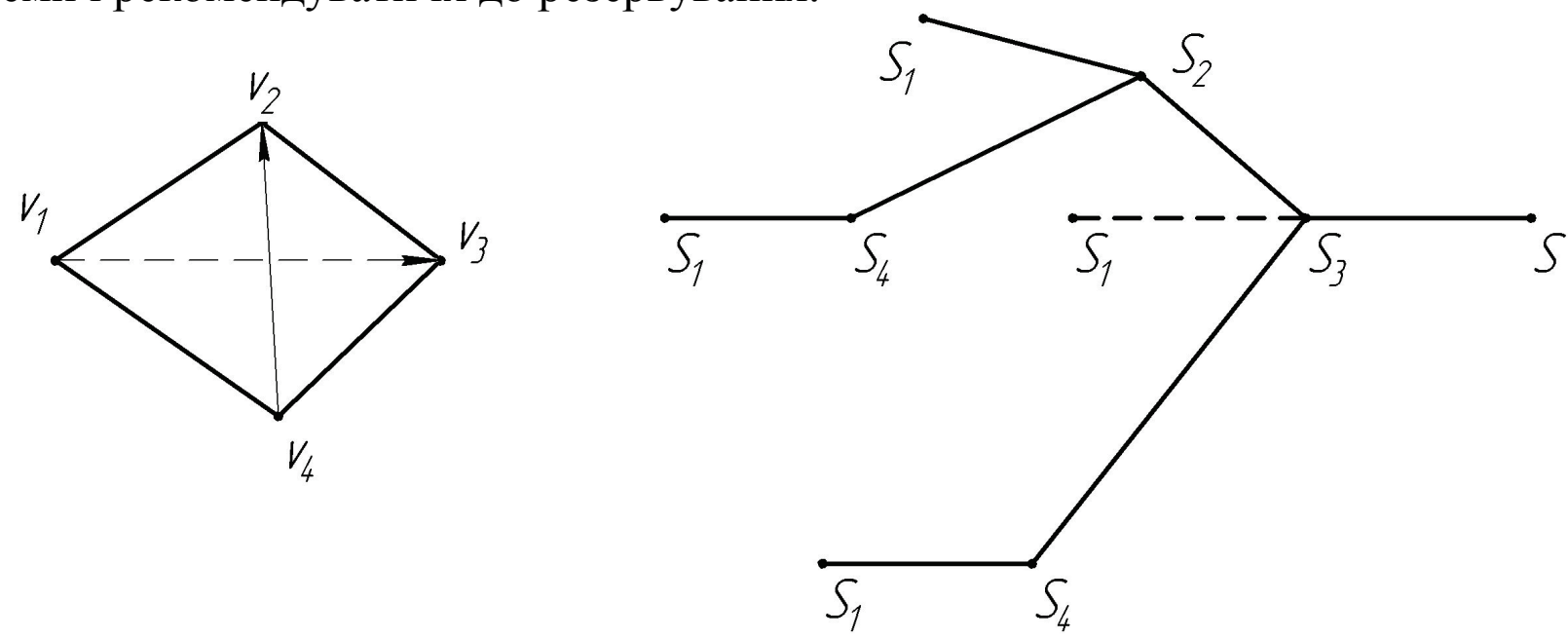

Рис. 1 Двополюсний граф $G$ і древо відмов $D$.

Досвід дослідження багатьох складних систем показує, що на початковому етапі аналізу їх елементи доцільно представляти у вигляді вершин графа, наділених певними властивостями, а взаємодію описувати за допомогою ребер. Будемо вважати тотожними наступні поняття: граф системи і структура системи, вершина графа i елемент системи, ребро графа i зв'язок між елементами системи.

Вершини $v_{1} \mathrm{i} v_{3}$ - полюсні вершини. На вершину $v_{1}$ подається сигнал, який повинен досягти вершини $v_{3}$. Головна подія $S$ - недосягнення сигналу 3 вершини $v_{1}$ вершину $v_{3}$. Проміжна подія $S_{i}, i=\{1,2,3,4\}$ - недосягнення сигналом вершини $v_{i}$. Пунктиром зображені резервні з'єднання.

Для будь-якого кінцевого графа будемо використовувати позначення: $G=(V, E)$, где $V=\left\{v_{i}\right\} i=1, n-$ множина вершин, а $E=\{e=(v, u)\}-$ множина його peбер.

Поширення впливу від одного елемента системи до іншого на графі системи будемо ставити орієнтованим ребром - ребром з заданими початком $\mathrm{i}$ кінцем. Орієнтоване ребро часто називають дугою, а граф з дугами - орграфом [5]. Орграф структури модельованої системи не буде мати петель (тобто дуг, кінець і початок яких збігається).

Надійністю елемента системи будемо вважати ймовірність $P(t<T)$ того, що елемент буде працездатний протягом часу $T$ з моменту початку експлуатації. Але завдання надійності елементів, приписуваних відповідним вершинам графа системи, мало для повного формального представлення системи. Вплив при проходженні від одного елемента до іншого втрачає свою "силу". Надійність елемента системи і частку зменшення впливу при переході від одного елемента 
до іншого можна отримати експериментально або при експертному аналізі.

Таким чином, на орграфе $G=(V, E)$ системи для вершини $v_{i} \in V, i \in\{1,2, \ldots, n\}$, вагою $w_{i}(t)=P_{v_{i}}(t<T) \epsilon$ величина надійності елемента системи, відповідного вершині $v_{i}$. А вагою $w\left(v_{i}, v_{j}\right)=\varepsilon_{i j}, j \in\{1,2, \ldots, n\}, i \neq j$, дуги $\left(v_{i}, v_{j}\right) \in E$, зі знаком «+», $\epsilon$ число $0<\varepsilon_{i j} \leq 1$, рівне частці впливу що передається, при переході від вершини $v_{i}$ до вершини $v_{j}$.

Тоді для $t>0$ для $i$-ї вершини графа $G$ визначимо імпульсний вплив

$$
w_{i}(t+1)=w_{i}(t) \prod_{k=1}^{\operatorname{deg} v_{i}} \varepsilon_{j i} i m p_{j}(t)
$$

або

$$
\operatorname{imp}_{i}(t+1)=\prod_{k=1}^{\operatorname{deg} v_{i}} \varepsilon_{j i} i m p_{j}(t)
$$

вважаючи при цьому, що deg $v_{i}$, - число що входить до вершин $v_{i}$ дуг.

Формули (2), (3) і (4) задають зміни ваг вершин графа $G=(V, E)$, тим самим визначаючи динаміку поширення зовнішніх впливів по системі.

Автономний імпульсний вплив на зваженому орграфе $G$ визначимо 3 вектором початкових значень $W(0)=\left(w j(0), w_{2}(0), \ldots, w_{n}(0)\right)$ i вектором імпульсів:

$$
\operatorname{Imp}(0)=\left(i m p_{1}(0), i m p_{2}(0), \ldots, i m p_{n}(0)\right)
$$

задає імпульс $\operatorname{imp}_{i}(0)$ в кожній вершині $V_{j}$ в момент часу $t=0$. Автономний імпульсний вплив в парі з вектором початкових значень описує стан системи в початковий момент часу, коли під вплив зовнішніх вражаючих впливів потрапляють всі елементи системи.

Автономне імпульсний вплив, в якому вектор $\operatorname{Imp}(0)=\left(1,1, \ldots, i m p_{i}(0), \ldots, 1\right)$, $\operatorname{imp}_{j}(0)>0$, має тільки $i$-ю відмінну від одиниці компоненту, назвемо простим впливом з початковою вершиною $v_{i} \in V$. Просте імпульсний вплив описує стан системи в початковий момент часу, коли зовнішній вплив вражає один 3 елементів системи. А саме, той який відповідає $i$-й вершині графа системи.

Висновок. Відповідно до описаної імпульсної дії на орграфі можна ввести різні критерії (ознаки) досягнення системою граничного стану. Наприклад, можна вважати, що система знаходиться в граничному стані, якщо надійність хоча б одного 3 найбільш значущих елементів системи нижче деякого допустимого рівня. Цей рівень будемо називати критичним рівнем надійності елемента. Введений критерій чітко розділяє докритичний і закритичних стан елемента навчально-виробничої системи. Якщо надійність елемента нижче критичного рівня, то елемент не в змозі виконувати покладених на нього функцій, або функціонувати необхідний час.

Література:

1. Носов П.С., Косенко Ю.І. Нечіткі моделі і методи ідентифікації та прогнозу стану інформаційної моделі студента // Межвузовский журнал 
"Автоматика. Автоматизация. Электротехнические комплексы и системы". Херсон: ХНТУ. №1(25)2010. - С. 26-30.

2. Ю.І. Косенко, П.С. Носов. Механізми ідентифікації та трансформації «знань» суб'єкта критичної інфраструктури // Інформаційні технології в освіті, науці та виробництві. Збірник наукових праць [Текст]. - Вип. 3(4) - Одеса: Наука і техніка 2013, С. 99-104.

3. П.С. Носов, В.Д. Яковенко, Ю.В. Арбузова. Модель професійних знань суб'єктів критичних інфраструктур // Управління проектами: стан та перспективи. Збірник наукових праць за матеріалами IX Міжнародної науковопрактичної конференції. - Миколаїв: НУК 2013. С. 212-215.

4. С.В. Руденко, В.Д. Гогунский. Оценка экологической безопасности в проектах: Монография . - Одесса: Феникс, 2006. - 153 С.

5. Ю.Н. Бардачев, Н.А. Соколова, В.Е. Ходаков / Под редакцией В.Е. Ходакова. Основы дискретной математики: учебное пособие - Херсон: Издательство ХГТУ - 2000. - 356 с.

Статья отправлена: 05.06.2017 г. (C) Дудченко O.M.

\section{ЦИТ: иа217-073}

DOI: 10.21893/2415-7538.2017-06-1-073

УДК 004.2

Гарматін В.Д., Максимюк А.В., Цимбаленко Я.Ю. МОДЕЛЮВАННЯ БІЗНЕС-ПРОЦЕСІВ ПІДГОТОВКИ ДОКУМЕНТІВ НА ЗАРАХУВАННЯ ПРАЦІВНИКІВ ДО УНІВЕРСИТЕТУ

Національний технічний університет Украӥни «Київський політехнічний інститут імені Ггоря Сікорського», Киї, проспект Перемоги 37, 03056

Garmatin V.D., Maksymiuk A.V., Tsymbalenko Y.Y. BUSINESS PROCESSES MODELING OF PREPARING DOCUMENTS FOR EMPLOYEES ENROLLMENT TO THE UNIVERSITY

National Technical University of Ukraine "Igor Sikorsky Kyiv Polytechnic Institute", Kyiv, Peremohy Avenue 37, 03056

Анотаиія. Автоматизована інформачійна система «Проект документу» спроектована співробітниками Конструкторського бюро інформаційних систем для вирішення проблем автоматизації відділу кадрів. Модуль «Наказ на зарахування» був розроблений як перма черга системи електронного документообігу. Система значно спростить та пришвидшити роботу з документами, забезпечити їх иұілісне збереження.

Ключові слова: відділ кадрів, підготовка документів, автоматизована система документообігу, Конструкторське бюро інформаційних систем.

Abstract. Automated Information System "Draft document" was designed by Design office of informational systems employees for informatization of human resource department of the university. Module "Order of admission" was created as first stage of document automation. System will greatly simplify and speed up the 